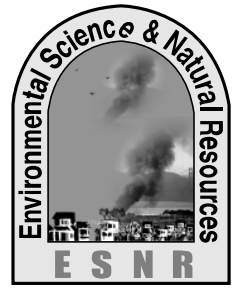

J. Environ. Sci. \& Natural Resources, 6(2): 157-162, 2013

ISSN 1999-7361

\title{
Assessment of Pond Water Quality for Fish Culture: A Case Study of Santosh Region in Tangail, Bangladesh
}

\author{
M. A. Munni, Z. Fardus, M. Y. Mia and R. Afrin
}

Department of Environmental Science and Resource Management, Mawlana Bhashani Science and Technology University, Santosh, Tangail- 1902, Bangladesh.

\begin{abstract}
This study deals with the assessment of pond water quality for fish culture by measuring various physicochemical parameters of water for fish culture from the seven identified ponds situated at Santosh region of Tangail Sadar Upazila. The parameters including temperature, $\mathrm{pH}, \mathrm{DO}, \mathrm{BOD}$, transparency, TDS, EC, acidity, alkalinity and hardness were investigated on 7 ponds viz. (1) Peer Sahjaman Dighi, (2) Bagbari Pond, (3) Aat Gazar pond, (4) Ayenamohol Pond, (5) Shahid Janani Jahanara Imam Hall (SJJIH) pond, (6) Raja pond, and (7) Rani pond. The obtained values of the investigated parameters were temperature 29-38. $3^{\circ} \mathrm{C}$, pH 6.8- 7.12, DO 1.1-6.9 mg/l, BOD 1.4-4.2 mg/l, transparency 32.5-57.5 cm, TDS 85-164 mg/l, EC 138-274 $\mu \mathrm{s} / \mathrm{cm}$, acidity $20-36.3 \mathrm{mg} / \mathrm{l}$, total alkalinity $43.5-62.5 \mathrm{mg} / \mathrm{l}$ and hardness $20-27 \mathrm{mg} / \mathrm{l}$. All the values were compared with the water quality standards for fish culture. The comparative analysis showed that most of the water quality parameters of the 7 ponds were suitable for fish culture while the temperatures recorded were higher in most cases than the desired level, and transparency, TDS and DO level were also fluctuated highly. From this investigation, it is recommended that necessary steps should be undertaken to improve the water quality of the ponds to a suitable level for fish culture. Steps should be implemented in such a way that they not ensure high yield fish production only to bring economic benefit but also conserve environmental quality.
\end{abstract}

Key words: Water quality, Physicochemical parameters, Fish culture

\section{Introduction}

Water is the culture environment for fish where they perform all their bodily functions. They are totally dependent upon water to breathe, feed and grow, excrete wastes, maintain a salt balance, and reproduce (Bronmark and Hansson, 2005).Water quality focuses on the various aspects of the physicochemical parameters of water by which state of a water body can easily be observed. It is the first most important limiting factor in fish culture which is normally governed by a number of parameters including color, odor, temperature, $\mathrm{pH}, \mathrm{DO}, \mathrm{BOD}$, TDS, EC, transparency, acidity, alkalinity and hardness (Boyd, 1990). Each of these parameters has a standard value for fish culture (James, 2000). A guiding principle of fish culture is that water quality and hence efficient production are a direct consequence of good water chemistry (Swann, 1993). Therefore, the maintenance of good water quality is essential for healthy fish culture. The majority of fish culture throughout the world is conducted in ponds. Pond habitats can easily be manipulated by controlling the water characteristics for an optimum environment yielding high level fish production (Swann, 1993). The present study aims at investigating the physicochemical parameters of pond water and comparing the analyzed values with the standard values for fish culture.

\section{Materials and methods}

The study was conducted on the seven selected ponds at Santosh of Tangail Sadar Upazila, Tangail (Fig.1). The investigated ponds were (1) Peer Sahjaman Dighi, (2) Bagbari Pond, (3) Aat Gazar pond, (4) Ayenamohol Pond, (5) Shahid Janani Jahanara Imam Hall (SJJIH) pond, (6) Raja pond, and (7) Rani pond. GPS reading was taken to know the latitude and longitude of each sampling pond.

Water samples were collected for physicochemical analysis from seven sampling ponds from 15 May 2013 to 15 June 2013 at ten days interval. Simple random sampling method was used for the primary data collection. Three different points from each pond were identified for random sampling. Samples were analyzed for some parameters namely temperature, $\mathrm{pH}$, dissolved oxygen (DO), biological oxygen demand (BOD), total dissolved solids (TDS), transparency, electrical conductivity (EC), alkalinity and hardness. Water temperature, $\mathrm{pH}, \mathrm{DO}$, TDS, EC and transparency of pond water were measured by thermometer, $\mathrm{pH}$ meter, DO meter, TDS meter, EC meter and Secchi disk respectively, where titration methods were used for the measurement of alkalinity and hardness. After the laboratory analysis, all the findings were integrated and presented in tables and charts and put in the report. 


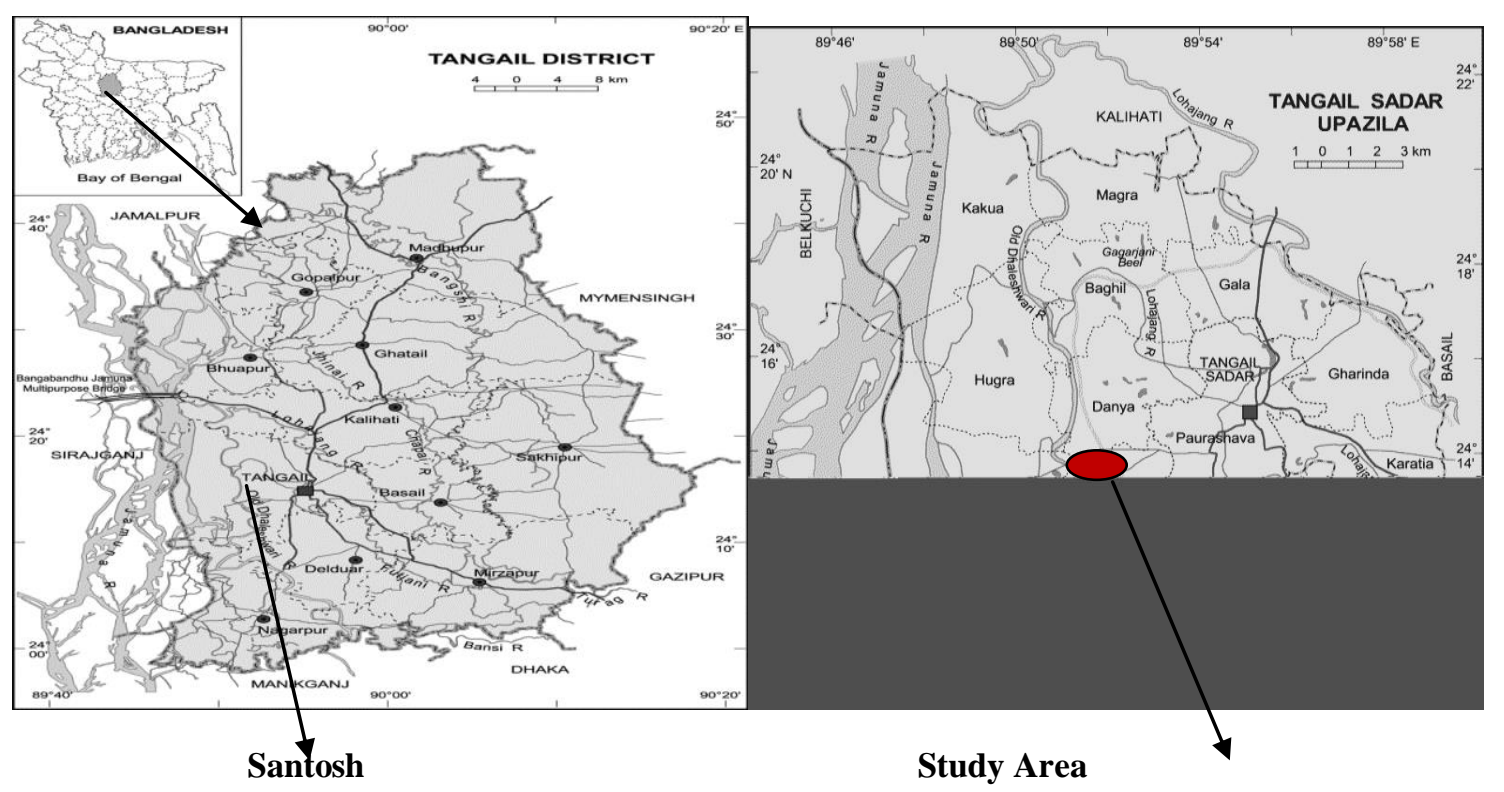

Fig. 1. Map showing the study area at Santosh, Tangail Sadar Upazila, Tangail.

\section{Results and discussions}

\section{Color and odor}

The color of the investigated pond water was observed visually. The color of study pond 1,2 and 5 were found to vary from light to deep green and color of pond 3, 4, 6 and 7 ranged from brown to gray. The deep green color represents higher planktons and light green color represents lower planktons. According to Das (1997), a well and phytoplankton enriched water body appears to be dark greenish blue, red or brown. The odor of the investigated pond water was smelt by nose. The odor of pond 1, 2 and 3 were fishy and odor of pond 4, 6 and 7 were not fishy. Pond 5 pertained bad odor due to the discharge of domestic effluents from girls' hostel. The odor of an ideal pond water is not fishy or odorless (Das, 1997).

\section{Water Temperature}

The ranges of temperature were from $30.3 \pm 0.58$ to $37.5 \pm 0.5^{\circ} \mathrm{C}, \quad 31.3 \pm 0.58$ to $37.3 \pm 1.15^{\circ} \mathrm{C}, 29 \pm 0$ to $36 \pm 0^{\circ} \mathrm{C}, 31.7 \pm 0.58$ to $37.3 \pm 0.58^{\circ} \mathrm{C}, 32.3 \pm 0.58$ to $38 \pm 0.5^{\circ} \mathrm{C}, 32.3 \pm 0$ to $38 \pm 0.58^{\circ} \mathrm{C}$ and $32 \pm 0$ to $38 \pm 1^{\circ} \mathrm{C}$ in $\mathrm{P}_{1}$ (pond 1), $\mathrm{P}_{2}, \mathrm{P}_{3}, \mathrm{P}_{4}, \mathrm{P}_{5}, \mathrm{P}_{6}$ and $\mathrm{P}_{7}$ respectively (Fig. 2). The maximum temperature was recorded in the month of June and the minimum temperature was found in the month of May.

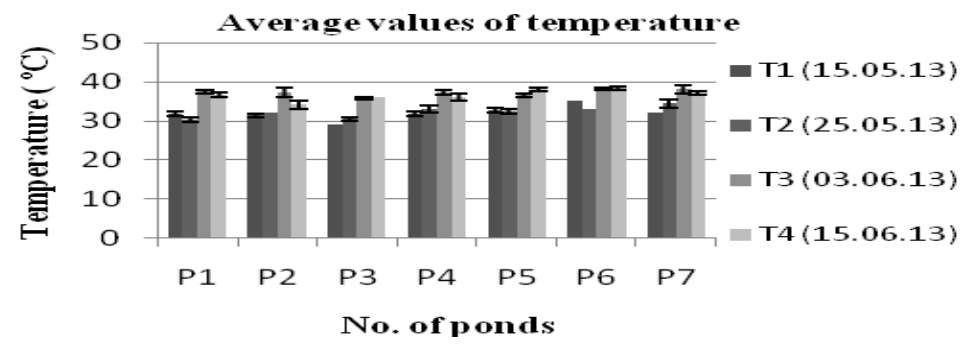

Fig. 2. Average values of temperature in 7 investigated ponds at different times.

For freshwater aquaculture the suitable range of temperature is about $25-32^{\circ} \mathrm{C}$ (Das, 1997). In the present study, temperatures recorded at $1^{\text {st }}$ and $2^{\text {nd }}$ sampling were within this suitable range and at $3^{\text {rd }}$ and $4^{\text {th }}$ sampling, the values were found to exceed the suitable range.

\section{pH}

The $\mathrm{pH}$ values in $\mathrm{P}_{1}, \mathrm{P}_{2}, \mathrm{P}_{3}, \mathrm{P}_{4}, \mathrm{P}_{5}, \mathrm{P}_{6}$ and $\mathrm{P}_{7}$ fluctuated from $7.04 \pm 0.02$ to $7.07 \pm 0.02,7.07 \pm 0.02$ to $7.12 \pm 0.04,6.84 \pm 0.05$ to $7.08 \pm 0.01,7.05 \pm 0.02$ to $7.11 \pm 0.03,7.04 \pm 0.02$ to $7.1 \pm 0.02,6.82 \pm 0.06$ to $6.94 \pm 0.02$, and $6.8 \pm 0.03$ to $6.95 \pm 0.03$ respectively (Fig. 3). 


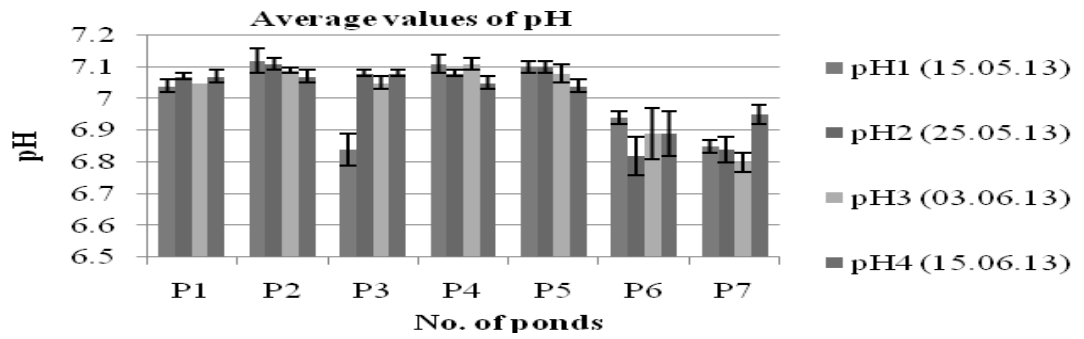

Fig. 3. Average values of $\mathrm{pH}$ in 7 investigated ponds at different times.

According to Swingle (1967) pH 6.5 to 9 is suitable for pond fish culture and the result of our investigation is within this similar $\mathrm{pH}$ ranges. So, it is estimated that the ponds have suitable $\mathrm{pH}$ ranges for fish culture.
DO

Before sunrise, the mean values of DO as recorded from water of $\mathrm{P}_{1}, \mathrm{P}_{2}, \mathrm{P}_{3}, \mathrm{P}_{4}, \mathrm{P}_{5}, \mathrm{P}_{6}$ and $\mathrm{P}_{7}$ were found to vary from $1.8 \pm 0.1$ to $2.5 \pm 0.1 \mathrm{mg} / \mathrm{l}, 1.6 \pm 0.15$ to $2.1 \pm 0.25 \mathrm{mg} / \mathrm{l}, 1.2 \pm 0.1$ to $1.9 \pm 0.2 \mathrm{mg} / \mathrm{l}, 1.5 \pm 0.2$ to $2.9 \pm 0.1 \mathrm{mg} / \mathrm{l}, 1.1 \pm 0.2$ to $2.1 \pm 0.4 \mathrm{mg} / \mathrm{l}, 1.7 \pm 0.21$ to $2.1 \pm 0.2 \mathrm{mg} / \mathrm{l}$, and $1.5 \pm 0.15$ to $2.9 \pm 0.25 \mathrm{mg} / \mathrm{l}$ respectively (Fig. 4).

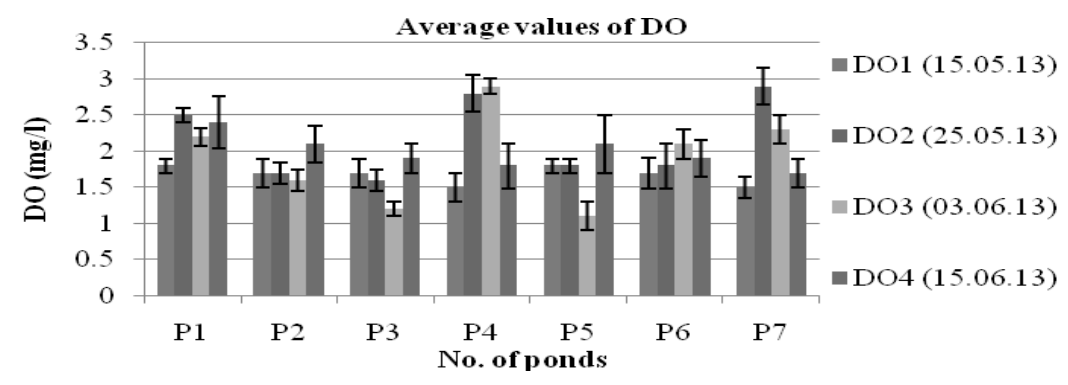

Fig. 4. Average values of DO in 7 investigated ponds before sunrise.

DO was also measured in the afternoon at two different dates (03.06.13 and 15.06.13). The ranges of DO were $6.2 \pm 0.25$ to $6.9 \pm 0.15 \mathrm{mg} / \mathrm{l}, 6 \pm 0.1$ to $6.1 \pm 0.25 \mathrm{mg} / \mathrm{l}, 5.6 \pm 0.15$ to $5.9 \pm 0.21 \mathrm{mg} / \mathrm{l}, 5.9 \pm 0.16$ to $6.1 \pm 0.21 \mathrm{mg} / \mathrm{l}, 6.2 \pm 0.2$ to $6.4 \pm 0.26 \mathrm{mg} / \mathrm{l}, 5.4 \pm 0.25$ to $5.6 \pm 0.06 \mathrm{mg} / \mathrm{l}$ and $5.8 \pm 0.06$ to $5.9 \pm 0.06 \mathrm{mg} / \mathrm{l}$ in the study pond 1-7 respectively (Fig. 5).

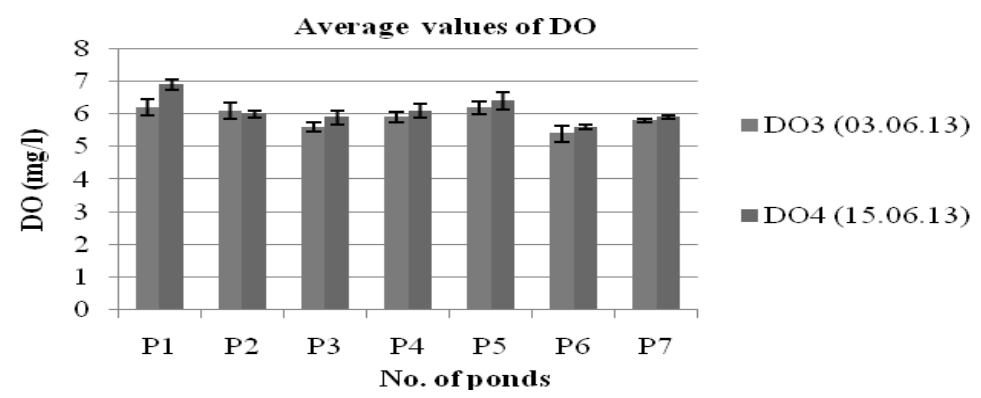

Fig. 5. Average values of $D O$ in 7 investigated ponds in the afternoon.

DO content should be above $6.0 \mathrm{mg} / \mathrm{l}$ for drinking water and more than $5.0 \mathrm{mg} / \mathrm{l}$ is suggested for fisheries, recreation and irrigation (EQS, 1997). It is revealed from the study that the DO values (measured in afternoon) were within the suitable DO level for fish culture.

\section{BOD}

The ranges of BOD recorded were $3.2 \pm 0.06$ to $4 \pm 0.2$ $\mathrm{mg} / \mathrm{l}, 3.6 \pm 0.15$ to $3.9 \pm 0.1 \mathrm{mg} / \mathrm{l}, 3.8 \pm 0.23$ to $4.4 \pm 0.12$ $\mathrm{mg} / \mathrm{l}, 4 \pm 0.32$ to $4.5 \pm 0.06 \mathrm{mg} / \mathrm{l}, 3.8 \pm 0.12$ to $3.8 \pm 0.15$ $\mathrm{mg} / \mathrm{l}, \quad 3.2 \pm 0.12$ to $3.6 \pm 0.12 \mathrm{mg} / \mathrm{l}$ and $4 \pm 0.31$ to $4.2 \pm 0.06 \mathrm{mg} / \mathrm{l}$ in $\mathrm{P} 1, \mathrm{P} 2, \mathrm{P} 3, \mathrm{P} 4, \mathrm{P} 5$, and $\mathrm{P} 7$ respectively (Fig. 6). 


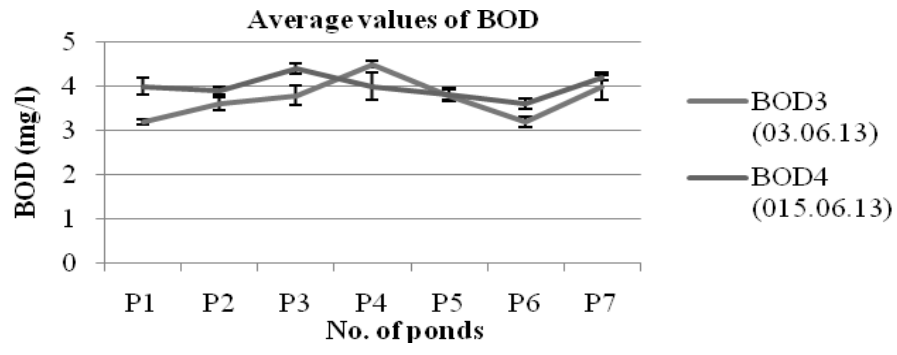

Fig. 6. Average values of BOD in 7 investigated ponds in the afternoon.

The acceptable BOD value for fish culture is less than 5mg/l (Das, 1997). According to DoE (2004), suitable BOD for fish culture is $5 \mathrm{mg} / \mathrm{l}$ or more. According to the EQS (1997), the tolerable limits of BOD are $0.2 \mathrm{mg} / \mathrm{l}$ for drinking, $3 \mathrm{mg} / \mathrm{l}$ for recreation, $6 \mathrm{mg} / \mathrm{l}$ for fish and $10 \mathrm{mg} / \mathrm{l} \mathrm{for} \mathrm{irrigation.}$
TDS

TDS values were found to fluctuate from $152 \pm 2$ to $164 \pm 1.7 \mathrm{mg} / 1,131 \pm 1$ to $151 \pm 1.7 \mathrm{mg} / \mathrm{l}, 85 \pm 2$ to $109 \pm 1$ $\mathrm{mg} / \mathrm{l}, 122 \pm 2.7$ to $144 \pm 2 \mathrm{mg} / \mathrm{l}, 133 \pm 2$ to $161 \pm 1 \mathrm{mg} / \mathrm{l}$, $136 \pm 1$ to $154 \pm 1 \mathrm{mg} / \mathrm{l}$, and $108 \pm 1.7$ to $135 \pm 1 \mathrm{mg} / \mathrm{l}$ respectively in $\mathrm{P}_{1}, \mathrm{P}_{2}, \mathrm{P}_{3}, \mathrm{P}_{4}, \mathrm{P}_{5}, \mathrm{P}_{6}$ and $\mathrm{P}_{7}$ (Fig. 7).

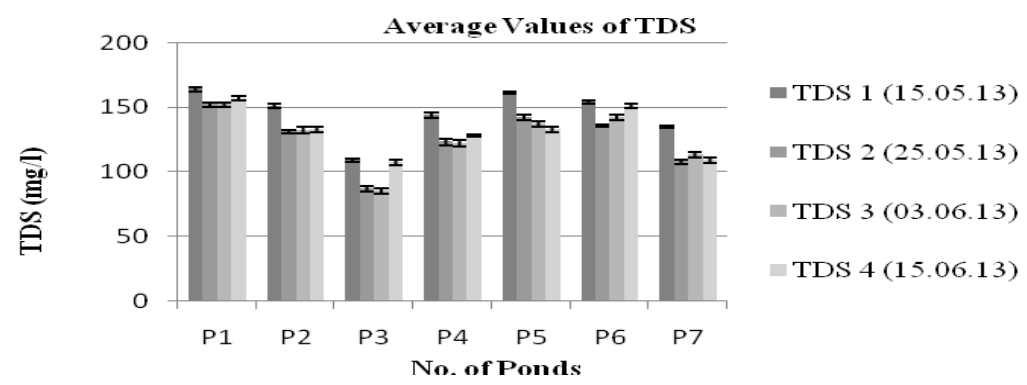

Fig. 7. Average values of TDS in 7 investigated ponds at different times.

In fish culture, a maximum TDS value of $400 \mathrm{mg} / \mathrm{l}$ is permissible for diverse fish production (James, 2000). The TDS values of all the study ponds were very low than the standard value.
EC

The EC values ranged from $253 \pm 2$ to $274 \pm 1 \mu \mathrm{s} / \mathrm{cm}$, $223 \pm 2.65$ to $244.3 \pm 2.08 \mu \mathrm{s} / \mathrm{cm}, \quad 143 \pm 2.65$ to $172.7 \pm 2.52 \mu \mathrm{s} / \mathrm{cm}, 212 \pm 2$ to $222.7 \pm 2.52 \mu \mathrm{s} / \mathrm{cm}$, $138 \pm 1$ to $252.7 \pm 2.52 \mu \mathrm{s} / \mathrm{cm}, \quad 222.7 \pm 2.52$ to $251.3 \pm 1.53 \mu \mathrm{s} / \mathrm{cm}$, and $172.7 \pm 2.52$ to $212 \pm 2 \mu \mathrm{s} / \mathrm{cm}$ in $\mathrm{P}_{1}, \mathrm{P}_{2}, \mathrm{P}_{3}, \mathrm{P}_{4}, \mathrm{P}_{5}, \mathrm{P}_{6}$ and $\mathrm{P}_{7}$ respectively (Fig. 8).

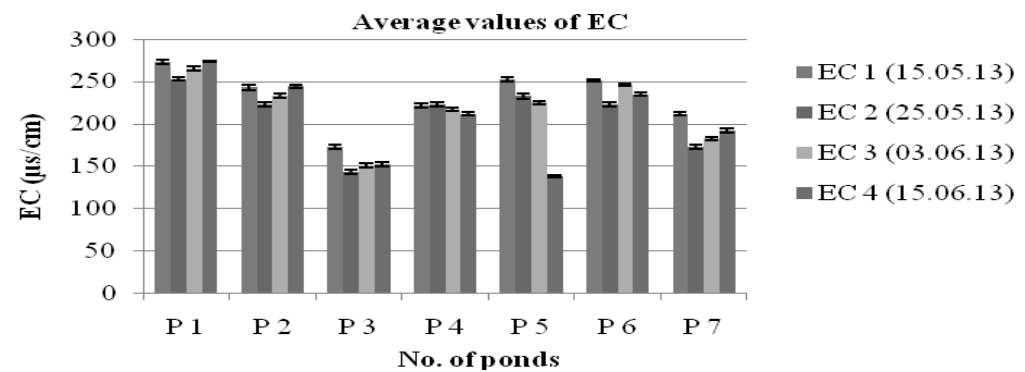

Fig. 8. Average values of EC in 7 investigated ponds at different times.

A freshwater body supporting good mixed fisheries has a range of EC between 150 and $500 \mu \mathrm{s} / \mathrm{cm}$ (James, 2000). According to the result of our investigation, the estimated values of each pond were within the standard range of EC and were significant for fish culture.

\section{Alkalinity}

Alkalinities of pond water were measured at 2 different dates and the values ranged from 52.5 \pm 3.5 to $57.5 \pm 3.5 \mathrm{mg} / \mathrm{l}, \quad 57.5 \pm 3.5$ to $57.5 \pm 3.5 \mathrm{mg} / \mathrm{l}$, $62.5 \pm 3.5$ to $57.5 \pm 3.5 \mathrm{mg} / \mathrm{l}, 52.5 \pm 3.5$ to $57.5 \pm 3.5$ $\mathrm{mg} / \mathrm{l}, \quad 57.5 \pm 3.5$ to $52.5 \pm 3.5 \mathrm{mg} / \mathrm{l}, \quad 43.5 \pm 3.5$ to $47.5 \pm 3.5 \mathrm{mg} / \mathrm{l}$ and $45 \pm 3.5$ to $47.5 \pm 1.8 \mathrm{mg} / \mathrm{l}$ in $\mathrm{P}_{1}, \mathrm{P}_{2}$, $\mathrm{P}_{3}, \mathrm{P}_{4}, \mathrm{P}_{5}, \mathrm{P}_{6}$ and $\mathrm{P}_{7}$ respectively (Fig. 9). 


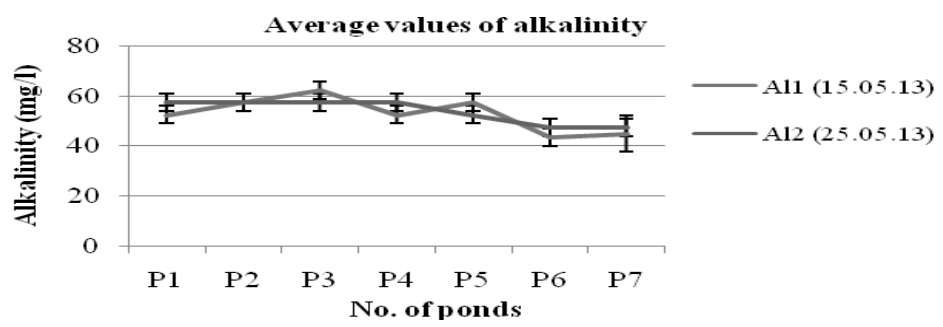

Fig. 9. Average values of alkalinity in 7 investigated ponds at different times.

The suitable value of alkalinity for aquaculture ranges from 50 to $300 \mathrm{mg} / \mathrm{l}$ (James, 2000). According to the result of our investigation, the estimated values of alkalinity were within this range.

\section{Hardness}

The values of hardness ranged from $23 \pm 1.4$ to $24 \pm 2.8$ $\mathrm{mg} / \mathrm{l}, 23 \pm 1.4$ to $24 \pm 2.8 \mathrm{mg} / \mathrm{l}, 20 \pm 2.8$ to $23 \pm 1.4 \mathrm{mg} / \mathrm{l}$, 26 to $27 \pm 1.4 \mathrm{mg} / \mathrm{l}, 25 \pm 1.4$ to $26 \pm 2.8 \mathrm{mg} / \mathrm{l}, 20 \pm 2.8$ to $23 \pm 1.4 \mathrm{mg} / \mathrm{l}$ and $23 \pm 1.4$ to $25 \pm 1.4 \mathrm{mg} / \mathrm{l}$ in $\mathrm{P}_{1}, \mathrm{P}_{2}, \mathrm{P}_{3}$, $\mathrm{P}_{4}, \mathrm{P}_{5}, \mathrm{P}_{6}$ and $\mathrm{P}_{7}$ respectively (Fig. 10).

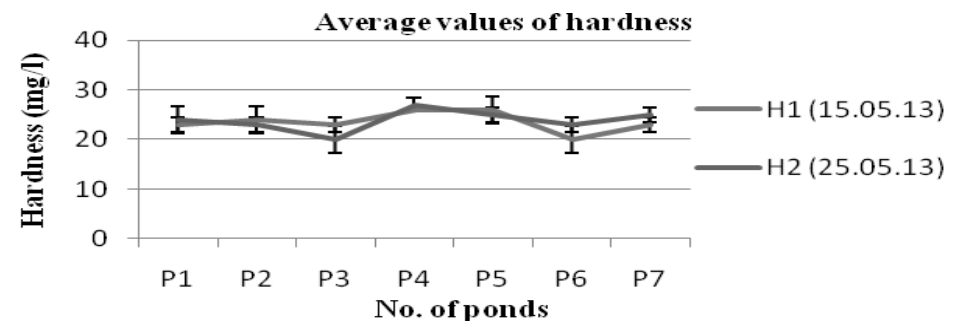

Fig. 10. Average values of hardness in 7 investigated ponds at different times.

According to Swingle (1967), a total hardness of 15 $\mathrm{mg} / \mathrm{l}$ or more is suitable for fish culture. Suitable hardness for soft water ranges between 20 to $75 \mathrm{mg} / 1$ (James, 2000). The average values of hardness of all the ponds were above $15 \mathrm{mg} / \mathrm{l}$ which are significant for fish culture.

\section{Conclusion}

The present research was conducted to assess the pond water quality for fish culture in Santosh of Tangail District. The average values of $\mathrm{pH}, \mathrm{BOD}$, $\mathrm{EC}$, total alkalinity and hardness of all the investigated ponds ( $\mathrm{pH}$ 6.8-7.12, BOD 1.4-4.2 mg/l, EC $138-274 \mu \mathrm{s} / \mathrm{cm}$, total alkalinity $43.5-62.5 \mathrm{mg} / \mathrm{l}$ and hardness $20-27 \mathrm{mg} / \mathrm{l}$ ) were acceptable for pond fish culture while the temperature and transparency recorded from most of the ponds were high than the desired level. The mean DO values of water (DO 1.1$6.9 \mathrm{mg} / \mathrm{l})$ were found to vary a little from pond to pond and a little abrupt condition was noticed. BOD of the pond 3, 4, and 7 were comparatively higher than that of pond $1,2,5$ and 6 . The ranges of TDS values $(85-164 \mathrm{mg} / \mathrm{l})$ from all the study ponds were very low than the standard value.

The present study recommended some proper steps to be undertaken at the investigated ponds to maintain and improve the water quality for fish culture:
1. Pond water quality should be monitored regularly;

2. Discharge of effluents into pond water should be stopped to control pollution;

3. Pond water surface should be agitated with bamboo poles or by swimming to increase DO level;

4. Proper fertilization should be ensured to maintain TDS and transparency level;

\section{References}

Boyd, C. E. 1990. Water quality in ponds for aquaculture. Alabama agricultural experiment station, Auburn University Ala.

Bronmark, C. and Hansson, L. A. 2005. The biology of lakes and ponds. Oxford University Press, Oxford. 285p.

Das, B. 1997. Fisheries and Fisheries Resources Management. Bangla Academy, Dhaka, Bangladesh, 153-155p.

DoE Standards. 2004. The People's Republic of Bangladesh. 
EQS (Environmental Quality Standard). 1997. Bangladesh Gazette, registered nr.DA-1, Ministry of Environment, Government of Bangladesh.

James, M. E. 2000. Water Quality and Recalculating Aquaculture Systems. Aquaculture Systems Technologies, LLC. New Orleans, LA. 16$17 \mathrm{p}, 28 \mathrm{p}$.
Swann, LaDon. 1993. Water Sources Used in Aquaculture. Illinois-Indiana Sea Grant Program. AS- 486. Purdue University, West Lafayette, IN. $4 \mathrm{p}$.

Swingle, H. S. 1967. Standardization of Chemical analyses for waters and pond mud. FAO Fish. Rep., 4(44): 397-421p. 